\title{
Endotoxin Enhances Tissue Factor and Suppresses Thrombomodulin Expression of Human Vascular Endothelium In Vitro
}

\author{
Kevin L. Moore, * Sharon P. Andreoli, ${ }^{*}$ Naomi L. Esmon, ${ }^{3}$ Charles T. Esmon, and Nils U. Bang" \\ Department of Medicine, Section of Hematology/Oncology, ${ }^{*}$ and Department of Pediatrics, Section of Nephrology, ${ }^{*}$ \\ Indiana University School of Medicine, Indianapolis, Indiana 46223; Oklahoma Medical Research Foundation, ${ }^{\S}$ \\ Oklahoma City, Oklahoma 73104; and Lilly Laboratory for Clinical Research," Indianapolis, Indiana 46202
}

\begin{abstract}
Endotoxemia is frequently associated clinically with disseminated intravascular coagulation (DIC); however, the mechanism of endotoxin action in vivo is unclear. Modulation of tissue factor (TF) and thrombomodulin (TM) expression on the endothelial surface may be relevant pathophysiologic mechanisms. Stimulation of human umbilical vein endothelial cells with endotoxin (1 $\mu \mathrm{g} / \mathrm{ml}$ ) increased surface TF activity from $1.52 \pm 0.84$ to $11.89 \pm 8.12 \mathrm{mU} / \mathrm{ml}^{-10} \mathrm{C}^{6}$ cells at $6 \mathrm{~h}(n=11)$ which returned to baseline by $24 \mathrm{~h}$. Repeated stimulation at $24 \mathrm{~h}$ resulted in renewed TF expression. Endotoxin $(1 \mu \mathrm{g} / \mathrm{ml})$ also caused a decrease in TM expression to $55.0 \pm 6.4 \%$ of control levels at $24 \mathrm{~h}(n=10)$ that remained depressed at $48 \mathrm{~h}$. Both effects were dose and serum dependent. A temporary rise in TF expression accompanied by a sustained fall in TM expression comprise a shift in the hemostatic properties of the endothelium that would favor intravascular coagulation and may contribute to the pathogenesis of DIC in gram-negative septicemia.
\end{abstract}

\section{Introduction}

The endothelial cell surface forms an effective thromboresistant surface between the intravascular and extravascular spaces. This thromboresistance is mediated by several mechanisms including the synthesis and secretion of prostacyclin (1), both urokinasetype and tissue-type plasminogen activators (2), and protein $S$ (3). In addition, endothelial cells have heparinlike molecules on their luminal surface that can accelerate antithrombin III-mediated thrombin inactivation (4). Endothelial cells also express a surface glycoprotein called thrombomodulin (5) which, when bound to thrombin, is a potent activator of circulating protein $C(5)$. Activated protein $C$ in turn functions as an anticoagulant by proteolytically degrading Factor $\mathrm{Va}(6,7)$ and Factor VIIIa (8) and in dogs as a profibrinolytic agent by indirect and as of yet unclear mechanisms (9).

Endothelial cells possess procoagulant properties as well. They synthesize von Willebrand factor (10), which plays a major role in platelet adhesion (11); they synthesize a plasminogen activator inhibitor (12) and have been shown to have the ability

Presented at the Xth International Congress on Thrombosis and Haemostasis, San Diego, CA, 15-19 July 1985.

Address reprint requests to Dr. Bang.

Received for publication 30 December 1985 and in revised form 12 September 1986.

J. Clin. Invest.

(c) The American Society for Clinical Investigation, Inc.

0021-9738/87/01/0124/07 \$1.00

Volume 79, January 1987, 124-130 to support the assembly of clotting factor complexes on their surfaces $(13,14)$.

Under physiologic conditions the thromboresistant properties of the endothelium are predominant. In some pathological states, however, this may not be the case. Gram-negative sepsis is frequently associated with varying degrees of disseminated intravascular coagulation (DIC), ${ }^{1}$ which is thought to be triggered by endotoxemia. The pathophysiology of DIC in gram-negative sepsis is complex and the mechanism(s) by which endotoxemia promotes intravascular coagulation in vivo is unclear. Recently, reports by several investigators provide evidence that the thromboresistance of the endothelial cell is diminished after exposure to endotoxin in the absence of other cell types. Endothelial cells have been shown to generate tissue factor activity (15-18) and release a plasminogen activator inhibitor (19) when stimulated with endotoxin in vitro.

In this paper we present data showing that the stimulation of tissue factor activity by endotoxin that has been previously reported is accompanied by a profound and sustained decline of thrombomodulin activity on the endothelial cell surface.

\section{Methods}

Materials. Medium 199 (M-199) was purchased from Whittaker M. A. Bioproducts, Walkersville, MA. Fetal bovine serum (FBS) was obtained from Hyclone Labs, Logan, UT (lot 110452, assayed by the manufacturer at $0.005 \mathrm{ng} / \mathrm{ml}$ endotoxin). Penicillin $\mathrm{G}$ and streptomycin were purchased from Eli Lilly \& Co., Indianapolis, IN. Porcine mucosal heparin was obtained from either Sigma Chemical Co., St. Louis, MO, or Eli Lilly \& Co., Indianapolis, IN. Endothelial cell growth factor was purchased from either Biomedical Technologies, Inc., Cambridge, MA, or Meloy Laboratories, Inc., Springfield, VA. Buminate, 25\% human serum albumin U.S. Pharmacopeia, was purchased from Travenol Laboratories, Inc., Glendale, CA, and type II collagenase was from Worthington Diagnostics Systems, Inc., Freehold, NJ. Lipopolysaccharide from Esche richia coli serotype 026:B6, prepared by the Boivin method, was purchased from Difco Laboratories, Detroit, MI, and limulus amebocyte lysate (LAL) was obtained from Cape Cod Associates, Woods Hole, MA. The synthetic chromogenic substrates, S-2222 ( $N$-benzoyl-L-Glu-GlyArg-pNA) and S-2238 (HD-Phe-Pip-Arg-pNA) were purchased from Helena Laboratories, Beaumont, TX. Spectrozym CA (H-D-Lys(Cbo)Pro-Arg-pNA - 2AcOH) was obtained from American Diagnostica, Inc. (Greenwich, CT). Hirudin was purchased from Pentapharm Ltd., Basel,

1. Abbreviations used in this paper: APC, activated protein C; DIC, disseminated intravascular coagulation; $\left[{ }^{3} \mathrm{H}\right] \mathrm{DOG}, 2$-deoxy-D- $\left[{ }^{3} \mathrm{H}\right]$ glucose; HBSS, Hanks' balanced salt solution; HSA, human serum albumin; HUVEC, human umbilical vein endothelial cell; LPS, lipopolysaccharide; MES, 2-( $N$-morpholino)ethanesulfonic acid; MOPS, 3-( $N$-morpholino)propanesulfonic acid; PA, plasminogen activator; PEG, polyethylene glycol; QAE, quaternary aminoethyl; SDS-PAGE, sodium dodecyl sulfate; TF, tissue factor; TNF, tumor necrosis factor; LAL, limulus amebocyte lysate. 
Table I. Characterization of Endotoxin-stimulated Procoagulant

\begin{tabular}{lllc}
\hline & & \multicolumn{2}{l}{ TF } \\
\cline { 3 - 4 } Cell treatment & Assay reaction mixture & 1 & 2 \\
\hline \multirow{2}{*}{ None } & VII, X & $\mathrm{mU} / \mathrm{ml} \cdot 10^{\circ} \mathrm{cells}$ & \\
Endotoxin & VII, X & $<0.9$ & $<1.0$ \\
Endotoxin & $\mathrm{X}$ & 8.31 & 5.02 \\
& & $<0.9$ & $<1.0$
\end{tabular}

In two experiments on cells derived from two different umbilical cords, confluent HUVEC were incubated with and without $1 \mu \mathrm{g} / \mathrm{ml}$ endotoxin for $6 \mathrm{~h}$ in M-199/20\% FBS. Tissue factor assays were then performed on duplicate wells using purified clotting factors as described in Methods.

Switzerland, and rabbit brain thromboplastin from Dade Diagnostics, Aguanda, Puerto Rico. 2-Deoxy-D- $\left[{ }^{3} \mathrm{H}\right]$ glucose $\left(\left[{ }^{3} \mathrm{H}\right] \mathrm{DOG}, 1 \mu \mathrm{Ci} / \mathrm{ml}, 21\right.$ $\mathrm{Ci} / \mathrm{mmol} \mathrm{sp}$ act) was purchased from Amersham Corp., Arlington Heights, IL. Factor VII-deficient and Factor X-deficient plasma was obtained from George King Biomedical, Inc., Overland Park, KS. Purified human $\alpha$-thrombin $(2850 \mathrm{NIH} \mathrm{U/ml)}$ was a gift of J. W. Fenton III, New York State Department of Health Laboratories, Albany, NY.

Preparation of barium citrate eluate. Citrated human fresh-frozen plasma was purchased from the Central Indiana Regional Blood Center. Barium citrate adsorption and elution was performed as described by Broze and Majerus (20). Dry ammonium sulfate was slowly added to the barium citrate eluate at $4^{\circ} \mathrm{C}$ to $28 \%$ saturation. The precipitate was removed by centrifugation. The supernatant was extensively dialyzed at $4^{\circ} \mathrm{C}$ against $0.1 \mathrm{M} \mathrm{NaCl}, 0.05 \mathrm{M}$ sodium phosphate, $25 \mathrm{mM}$ benzamidine $\mathrm{HCl}, \mathrm{pH} 7.4$, concentrated by dialysis against polyethylene glycol (PEG)20,000 and stored in $1-\mathrm{ml}$ aliquots at $-70^{\circ} \mathrm{C}$ until use. Prior to use, an aliquot of eluate was dialyzed overnight against 2 liters $0.1 \mathrm{M} \mathrm{NaCl}, 0.05$ $\mathrm{M}$ sodium phosphate, $\mathrm{pH} 7.4$, at $4^{\circ} \mathrm{C}$ to remove benzamidine. The eluate contained $9.4 \mathrm{U} / \mathrm{ml}$ Factor VII and $8.4 \mathrm{U} / \mathrm{ml}$ Factor $\mathrm{X}$ as assayed by conventional one-stage clotting assays using congenital factor-deficient plasma.

Preparation of purified proteins. Human protein C, protein S, Factor VII and Factor $\mathrm{X}$ were partially purified from citrated human plasma by quaternary aminoethyl (QAE) adsorption and elution as described (21). The eluate containing the vitamin K-dependent factors was then sequentially batch adsorbed with a monoclonal anti-human protein $S$ affinity resin followed by a monoclonal anti-human protein $\mathrm{C}$ affinity resin. The anti-protein $\mathrm{S}$ monoclonal antibody, termed HPS2 and the anti-protein $\mathrm{C}$ monoclonal antibody, termed HPC4, were coupled to Affigel 10 (Bio-Rad Laboratories, Richmond, VA) according to the instructions of the manufacturer. The final antibody concentration on these gels was $5 \mathrm{mg} / \mathrm{ml}$ resin. Protein $S$ was eluted from the HPS2 resin with

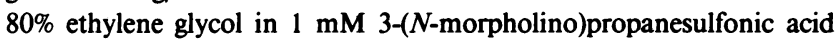
(MOPS), $\mathrm{pH} 7.5$, and protein $\mathrm{C}$ was eluted from the HPC4 resin with 2 mM EDTA in $0.1 \mathrm{M} \mathrm{NaCl}, 20 \mathrm{mM}$ Tris, pH 7.5. Protein $\mathrm{C}$ was activated according to D'Angelo et al. (22). Human Gla-domainless protein C was prepared as described by Esmon et al. for the bovine molecule (23).

The QAE eluate after adsorption with the monoclonal antibody resins was adsorbed with $\mathrm{BaSO}_{4}$ and eluted as previously described (21). The barium eluate was brought to $70 \%$ saturation with dry ammonium sulfate and the precipitate collected by centrifugation. The precipitate was re

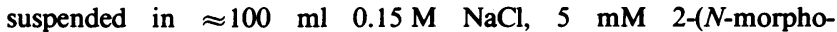
lino)ethanesulfonic acid (MES), $1 \mathrm{mM}$ benzamidine, $\mathrm{pH} 6.0$, and desalted on a $5 \times 40$-cm Sephadex G-75 column equilibrated in the same buffer. The desalted material was loaded onto a $2.5 \times 50 \mathrm{~cm}$ DEAE-Sepharose column, washed extensively and developed at $4^{\circ} \mathrm{C}$ with a 1,300 -ml linear gradient from $0.15 \mathrm{M}$ to $0.5 \mathrm{M} \mathrm{NaCl}$ in $5 \mathrm{mM} \mathrm{MES,} 1 \mathrm{mM}$ benzamidine, pH 6.0.

Factor VII containing fractions were pooled and dialyzed against 0.1 $\mathrm{M} \mathrm{NaCl}, 20 \mathrm{mM}$ Tris, $1 \mathrm{mM}$ benzamidine, $\mathrm{pH}$ 7.5. Factor VII was further purified by chromatography on a $5 \times 50 \mathrm{~mm}$ Mono $\mathrm{Q}$ column (Pharmacia Fine Chemicals, Piscataway, NJ). The column was developed with a 20 -ml linear gradient from 0 to $0.5 \mathrm{M} \mathrm{NaCl}$ in $20 \mathrm{mM}$ Tris, 5 $\mathrm{mM} \mathrm{CaCl}_{2}, \mathrm{pH} 7.5$, at a $2-\mathrm{ml} / \mathrm{min}$ flow rate. The Factor VII activity, which eluted at $\approx 0.15 \mathrm{M} \mathrm{NaCl}$, was pooled and made $5 \mathrm{mM}$ in EDTA. This material was reapplied to the Mono $Q$ column and the column developed with a 20-ml linear gradient from 0.1 to $0.7 \mathrm{M} \mathrm{NaCl}$ and in $20 \mathrm{mM}$ Tris, $\mathrm{pH}$ 7.5. Factor VII eluted at $\sim 0.38 \mathrm{M} \mathrm{NaCl}$. This protein was homogeneous by sodium dodecyl sulfate polyacrylamide gel electrophoresis (SDS-PAGE) performed according to Laemmli (24) and had a specific activity of $3,760 \mathrm{U} / \mathrm{mg}$.

Factor $\mathrm{X}$ containing fractions of the DEAE-Sepharose column were pooled and dialyzed against $50 \mathrm{mM}$ imidazole, $1 \mathrm{mM}$ benzamidine, $\mathrm{pH}$ 6.0 , and further purified by chromatography on heparin agarose as described by Miletich et al. (25). The Factor $X$ peak was dialyzed against $0.1 \mathrm{M} \mathrm{NaCl}, 20 \mathrm{mM}$ Tris, $1 \mathrm{mM}$ benzamidine, $\mathrm{pH} 7.5$, loaded onto a 5 $\times 50 \mathrm{~mm}$ Mono $\mathrm{Q}$ column and developed with a 20 -ml linear gradient from 0.1 to $0.7 \mathrm{M} \mathrm{NaCl}$ in $20 \mathrm{mM}$ Tris, $\mathrm{pH} 7.5$, at a flow rate of $2 \mathrm{ml} /$ min. Factor $\mathrm{X}$ activity eluted at $\approx 0.45 \mathrm{M} \mathrm{NaCl}$ and was homogeneous by SDS-PAGE. This protein had a specific activity of $210 \mathrm{U} / \mathrm{mg}$.

Endotoxin assays. All solutions that came into contact with cells prior to endotoxin stimulation were assayed at $<0.05 \mathrm{ng} / \mathrm{ml}$ endotoxin using the LAL test performed according to the supplier in pyrogen-free $12 \times 75 \mathrm{~mm}$ polystyrene tubes (Fisher Scientific Co., Pittsburgh, PA). Complete media was assayed using the serial dilution method described by Edwards et al. (26). Under our conditions, the detection limit of this lysate was $0.05 \mathrm{ng} / \mathrm{ml}$ E. coli serotype 026:B6 LPS.

Cell cultures. Endothelial cells were harvested from umbilical cord veins less than $8 \mathrm{~h}$ after delivery as described by Jaffe et al. (27) and grown to confluence in M-199 supplemented with $20 \%$ FBS, $90 \mu \mathrm{g} / \mathrm{ml}$ porcine mucosal heparin, $100 \mu \mathrm{g} / \mathrm{ml}$ endothelial cell mitogen, $100 \mu \mathrm{g} /$ $\mathrm{ml}$ penicillin $\mathrm{G}$ and $100 \mu \mathrm{g} / \mathrm{ml}$ streptomycin, in tissue culture flasks (75 $\mathrm{cm}^{2}$, Corning Glass Works, Corning, $\mathrm{NY}$ ) at $37^{\circ} \mathrm{C}, 5 \% \mathrm{CO}_{2}$. Cells were passed using $0.1 \%$ collagenase in phosphate-buffered saline (PBS) and grown to confluence in 16-mm diam tissue culture wells (Cluster 24, Costar Data Packaging, Cambridge, MA). All experiments were performed on cells after only one passage and at least $4 \mathrm{~d}$ after passage.

The endothelial cell monolayers demonstrated the typical cobblestone morphology of endothelial cells and stained positive for Factor VIII antigen by indirect immunofluorescent staining.

Tissue factor assays. The surface expression of tissue factor was measured using a two-stage amidolytic assay. Tissue culture wells $(16 \mathrm{~mm}$ diam) containing confluent human umbilical vein endothelial cell (HUVEC) were washed four times with M-199/0.5\% human serum albumin (HSA) prewarmed to $37^{\circ} \mathrm{C}$. After the last wash, $0.5 \mathrm{ml} \mathrm{M}-199$ (serum free) was added to the test wells. In the first stage of the assay, $25 \mu \mathrm{l}$ human barium citrate eluate was added to each washed monolayer and incubated for $10 \mathrm{~min}$ on a rotating platform $(120 \mathrm{cycles} / \mathrm{min})$ at room temperature. In the second stage, $0.4 \mathrm{ml}$ of conditioned media was combined with $0.2 \mathrm{ml} 1 \mathrm{mM} \mathrm{S}-2222$ in a cuvette. The $\Delta O D_{405} / \mathrm{min}$ was measured using a model 35 spectrophotometer (Beckman Instruments, Inc., Fullerton, CA). After assay, the cells were removed from each well with $0.25 \%$ trypsin and counted with a hemocytometer. In certain experiments purified human Factor X (final concentration $4 \mu \mathrm{g} / \mathrm{ml}$ ) with or without purified human Factor VII (final concentration $0.5 \mu \mathrm{g} / \mathrm{ml}$ ) were added in the first stage of the assay instead of barium citrate eluate.

The tissue factor activity was obtained from a standard curve (log $\left[\Delta \mathrm{OD}_{405} / \mathrm{min}\right]$ vs. $\left.\log [\mathrm{mU} / \mathrm{ml}]\right)$ constructed using serial dilutions of rabbit brain thromboplastin in M-199 assayed as described above. Undiluted thromboplastin was arbitrarily assigned a value of $1 \mathrm{U} / \mathrm{ml}$. Standard curves, performed with each assay, were linear from 0.1 to 100 $\mathrm{mU} / \mathrm{ml}$ and did not change significantly over $6 \mathrm{mo}$. The tissue factor activity was normalized to the cell counts from the same well and expressed as milliunits of tissue factor $/ \mathrm{ml}-10^{6}$ cells.

Thrombomodulin assays. The surface expression of thrombomodulin was also measured using a two-stage amidolytic assay. Tissue culture wells ( $16 \mathrm{~mm}$ diam) containing confluent HUVEC were washed as described above. In the first stage of the assay, human $\alpha$-thrombin (final concentration, $0.1 \mathrm{NIH} \mathrm{U} / \mathrm{ml}$ ) and human protein $\mathrm{C}$ (final concentration, $12 \mu \mathrm{g} / \mathrm{ml}$ ) was added to the monolayers containing $0.5 \mathrm{ml} \mathrm{M}-199$. The 
cells were incubated for $60 \mathrm{~min}$ at $37^{\circ} \mathrm{C}, 5 \% \mathrm{CO}_{2}$. Excess hirudin was then added (final concentration, 4 antithrombin $\mathrm{U} / \mathrm{ml}$ ) to block thrombin activity. Controls containing $\alpha$-thrombin and protein $\mathrm{C}$ in the absence of cells were treated similarly. In the second stage, $0.14 \mathrm{ml}$ of conditioned media was combined with $60 \mu \mathrm{l}$ of $1.5 \mathrm{mM} \mathrm{S}-2238$ in microliter wells and $\mathrm{OD}_{405}$ measured with an automatic plate reader after $5 \mathrm{~min}$ at room temperature. In the presence of hirudin, S-2238 hydrolysis exclusively measures activated protein $C$ activity. After assay, the cells were removed from each well with $0.25 \%$ trypsin and counted with a hemocytometer.

The thrombomodulin activity was obtained from a standard curve $\left(\mathrm{OD}_{405} \mathrm{vs} . \mu \mathrm{g} / \mathrm{ml}\right.$ activated protein $\left.\mathrm{C}, \mathrm{APC}\right)$ constructed using serial dilutions of purified human APC in M-199, assayed as described above. The thrombomodulin activity was normalized to the cell counts from the same wells and expressed as micrograms APC $/ \mathrm{ml}-10^{6}$ cells.

Endothelial cells were $>95 \%$ viable by trypan blue exclusion after these assays.

$\left[{ }^{3} \mathrm{H}\right] D O G$ release assay. Endothelial cell membrane integrity was determined using a $\left[{ }^{3} \mathrm{H}\right] \mathrm{DOG}$ release assay as previously described (28). Briefly, confluent HUVEC monolayers in 96-well tissue culture plates were labeled with $0.1 \mathrm{ml}$ of $\left.2.5 \mathrm{mCi} / \mathrm{ml} \mathrm{[}{ }^{3} \mathrm{H}\right] \mathrm{DOG}$ for $18 \mathrm{~h}$. Following the labeling period, the media was removed and the monolayers washed five times with $0.1 \mathrm{ml}$ Hanks' buffered salt solution (HBSS)/0.5\% HSA to remove excess radiolabel. The cells were then incubated in M-199/ $20 \%$ FBS with varying concentrations of endotoxin $(0-100 \mu \mathrm{g} / \mathrm{ml})$. After incubation from 1 to $4 \mathrm{~h}$ at $37^{\circ} \mathrm{C}, 5 \% \mathrm{CO}_{2}$, the supernatant was removed and the cells washed twice with HBSS $/ 0.5 \%$ HSA. The cell monolayers were then dissolved with $2 \%$ Triton X-100. The supernatant, cell washes and solubilized cells were then counted in a liquid scintillation beta counter (Packard Instruments Co., Downers Grove, IL). The percent release was then calculated as $(A / A+B) \times 100$, where $A$ represents the counts per minute in the supernatant plus cell washes and $B$ represents the counts per minute in the solubilized cell fraction. Specific release was determined by subtracting the percent release from control cells from the percent release from endotoxin-stimulated cells. Assays were performed on cells derived from three separate cell harvests after one passage. For each endotoxin concentration and each time point tested, four parallel wells of HUVEC were assayed separately as described. Control assays incubated without endotoxin were performed on eight parallel wells.

\section{Results}

Stimulation of tissue factor activity. When we examined the effect of endotoxin on surface expression of tissue factor (TF) on endothelial cells in culture, we observed a time-dependent stimulation of tissue factor activity (Fig. 1). Increased tissue factor activity was observed as early as $2 \mathrm{~h}$ and reached a maximum at $6 \mathrm{~h}$ after endotoxin stimulation. Tissue factor expression began returning to baseline by $8 \mathrm{~h}$ and was at $44.3 \%$ of maximal expression at $12 \mathrm{~h}$. At $24 \mathrm{~h}$, the surface expression of tissue factor returned to baseline control levels. Tissue factor expression in control wells did not change significantly over the 24-h incubation period. In a series of experiments on cells derived from 11 different umbilical cord veins, control monolayers expressed $1.52 \pm 0.84 \mathrm{mU} \mathrm{TF} / \mathrm{ml}-10^{6}$ cells (mean $\pm \mathrm{SD}$ ) and monolayers stimulated with $1 \mu \mathrm{g} / \mathrm{ml}$ endotoxin expressed $11.89 \pm 8.12 \mathrm{mU}$ $\mathrm{TF} / \mathrm{ml}-10^{6}$ cells (mean $\left.\pm \mathrm{SD}\right)$ after $6 \mathrm{~h}$ incubation $(P<0.001$, paired $t$ test). That the ability of endotoxin-stimulated HUVEC to generate Factor $\mathrm{Xa}$ is due to the expression of tissue factor and not a Factor $X$ activator was confirmed by assays using purified human Factor $\mathrm{X}$ in the presence and absence of purified human Factor VII (Table I). Endotoxin-stimulated tissue factor expression occurred without discernable morphological changes assessed by phase contrast microscopy, and without detectable

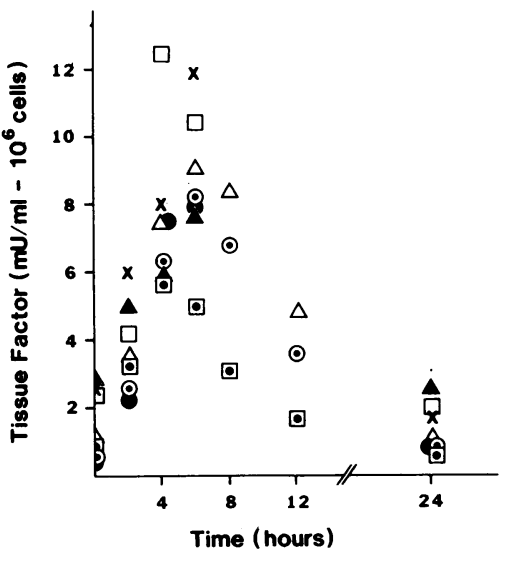

Figure 1. Time course of endotoxin-stimulated tissue factor expression. Confluent HUVEC monolayers derived from six different umbilical cord veins were assayed for surface expression of tissue factor after incubation with $1 \mu \mathrm{g} / \mathrm{ml}$ endotoxin in M-199/ 20\% FBS for the indicated time periods. Data derived from each of the six endothelial cell lines is represented by a different symbol. Each point represents the average of assays performed on duplicate wells. Assays on cultures marked $(\square, X, \Delta, \Delta, \bullet)$ were performed with barium citrate eluate as the source for coagulation factors. Two of the cultures $(\odot, \square)$ were assayed with purified reagents. The best responding (peak TF $24 \mathrm{mU} / 10^{6}$ cells) and the worst responding ( $3.5 \mathrm{mU} / 10^{6}$ cells) cultures were not shown in the figure.

loss of membrane integrity, measured by $\left[{ }^{3} \mathrm{H}\right] \mathrm{DOG}$ release $(<2.8 \%$ specific release) at endotoxin doses up to $100 \mu \mathrm{g} / \mathrm{ml}$.

Dose-response experiments indicated that tissue factor expression in response to endotoxin was dose dependent (Fig. 2) and that the threshold endotoxin concentration approached the sensitivity of the LAL assay.

Endotoxin-stimulated tissue factor expression did not occur in the absence of serum (Fig. 3). The effect of serum on tissue factor expression appeared to be dose dependent. This effect was not due to complement activation because the FBS used had no detectable hemolytic complement by standard $\mathrm{CH}_{50}$ assay.

The ability of endothelial cells to respond to restimulation by endotoxin was also studied (Fig. 4). After initial endotoxin exposure, the time course of tissue factor expression and subsequent down regulation was identical to that described above. In addition, the tissue factor expression declined to baseline

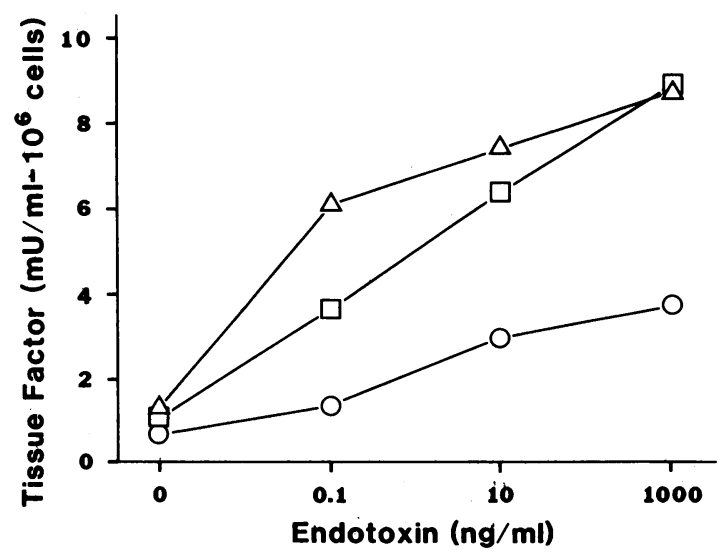

Figure 2. Effect of endotoxin concentration on endothelial cell tissue factor expression. Confluent HUVEC monolayers derived from three different umbilical cord veins were assayed for surface expression of tissue factor after incubation with endotoxin in M-199/20\% FBS for 6 h. Data derived from each of the three endothelial cell lines is represented by a different symbol. Each point represents the average of assays performed on duplicate wells. 


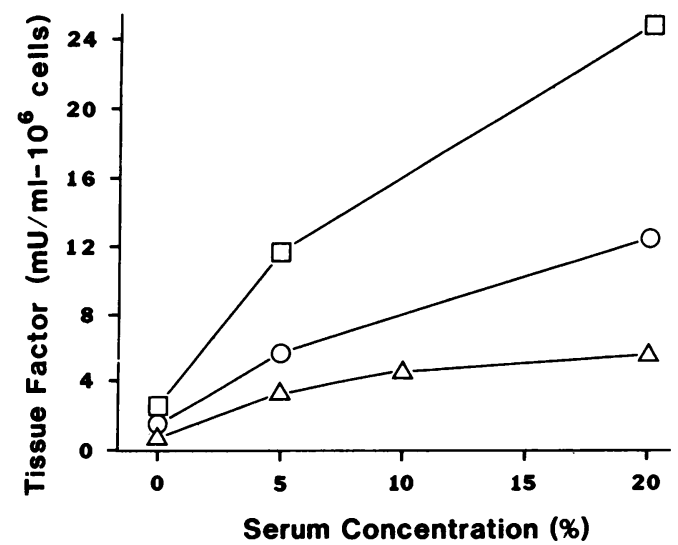

Figure 3. Effect of serum concentration on endotoxin-stimulated tissue factor expression. Confluent HUVEC monolayers derived from three different umbilical cord veins were assayed for surface expression of tissue factor after incubation with $1 \mu \mathrm{g} / \mathrm{ml}$ endotoxin in M-199 with $0-20 \%$ FBS for $6 \mathrm{~h}$. Data derived from each of the three endothelial cell lines is represented by a different symbol. Each point represents the average of assays performed on duplicate wells.

whether or not endotoxin was removed from the cultures at 6 h. Cells initially stimulated for $6 \mathrm{~h}$ (open squares) expressed levels of tissue factor activity comparable to that after the first exposure, and with a similar time course, when restimulated. Cells incubated with endotoxin for the preceding $24 \mathrm{~h}$ (open triangles) also expressed increased tissue factor activity when restimulated, albeit at lower levels.

Suppression of thrombomodulin activity. We next examined the effect of endotoxin on the surface expression of thrombomodulin activity (Fig. 5). Thrombomodulin expression was observed to decline between 6 and $12 \mathrm{~h}$, continued to decline until

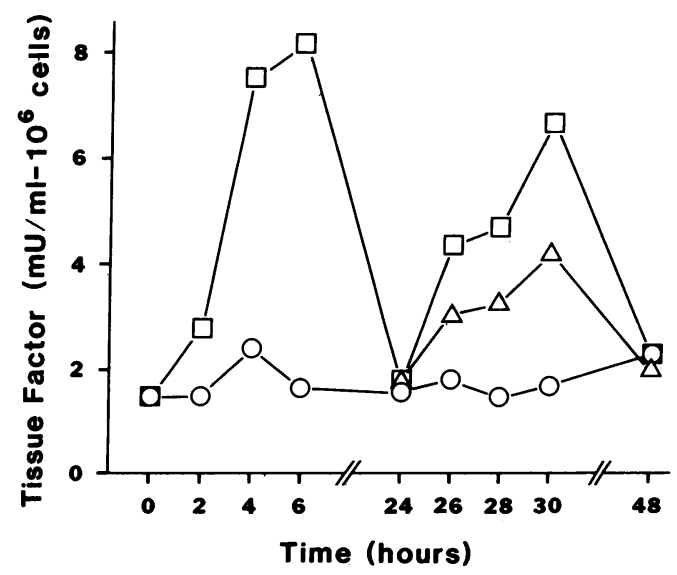

Figure 4. Restimulation of tissue factor expression in response to endotoxin. Sequential tissue factor assays were performed on parallel sets of confluent HUVEC monolayers derived from the same umbilical cord vein. One set, incubated with M-199/20\% FBS for $48 \mathrm{~h}$ (media changed at $24 \mathrm{~h}$ ), served as controls (O). A second set ( $\square$ ) was incubated with $1 \mu \mathrm{g} / \mathrm{ml}$ endotoxin in M-199/20\% FBS for the initial $6 \mathrm{~h}$ after which the endotoxin containing media was removed and fresh endotoxin-free M-199/20\% FBS added. At 24 h $1 \mu \mathrm{g}$ M-199/20\% FBS with $1 \mu \mathrm{g} / \mathrm{ml}$ endotoxin was again added. A third set $(\Delta)$ was incubated with $1 \mu \mathrm{g} / \mathrm{ml}$ endotoxin in M-199/20\% FBS for the initial $24 \mathrm{~h}$ after which the media was removed and fresh M-199/20\% FBS containing $1 \mu \mathrm{g} / \mathrm{ml}$ endotoxin added. Each point represents the average of assays performed on duplicate wells.

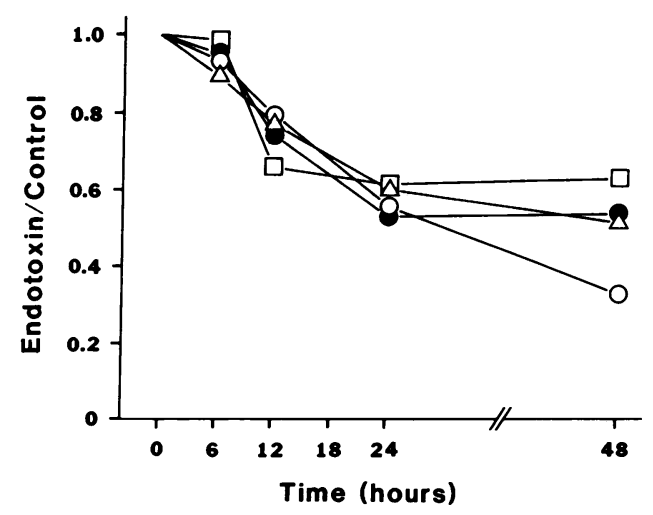

Figure 5. Time course of endotoxin-stimulated thrombomodulin suppression. Confluent HUVEC monolayers derived from four different umbilical cord veins were assayed for surface thrombomodulin activity after incubation with $1 \mu \mathrm{g} / \mathrm{ml}$ endotoxin in M-199/20\% FBS for the indicated time periods. Data derived from each of the four endothelial cell lines is represented by a different symbol. Each point represents the ratio of thrombomodulin activity on endotoxin-stimulated cells (average of four replicate wells) to the activity on control unstimulated cells (averaged four replicate wells) assayed at the same time.

$24 \mathrm{~h}$, and remained depressed up to $48 \mathrm{~h}$ after addition of endotoxin. In a series of experiments on cells derived from 10 different umbilical cord veins, control monolayers generated $40.13 \pm 19.0 \mu \mathrm{g} \mathrm{APC} / \mathrm{ml}-10^{6}$ cells (mean $\pm \mathrm{SD}$ ) and monolayers stimulated with $1 \mu \mathrm{g} / \mathrm{ml}$ endotoxin generated $21.95 \pm 12.10 \mu \mathrm{g}$ APC $/ \mathrm{ml}-10^{6}$ cells (mean $\left.\pm \mathrm{SD}\right)$ after $24 \mathrm{~h}$ incubation $(P<0.001$, paired $t$ test). Under the assay conditions, no detectable S-2238 amidolytic activity was generated on either control or endotoxinstimulated HUVEC monolayers when protein $C$ was deleted from the first stage of the assay. Therefore, the amidolytic activity generated on the cells was due exclusively to APC.

Dose-response experiments indicated that endotoxin-stimulated thrombomodulin suppression is also dose dependent. Concentrations of endotoxin required to initiate stimulation of tissue factor production and suppress thrombomodulin activity were comparable (Figs. 2 and 6).

To determine if thrombomodulin suppression also required serum, HUVEC monolayers were incubated with $1 \mu \mathrm{g} / \mathrm{ml}$ en-

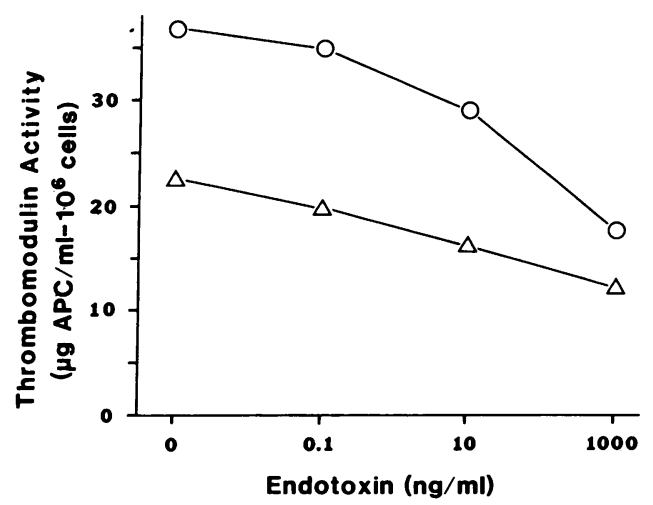

Figure 6. Effect of endotoxin concentration on endothelial cell thrombomodulin expression. Confluent HUVEC derived from two different umbilical cord veins were assayed for surface thrombomodulin activity after incubation with endotoxin in M-199/20\% FBS. Data derived from each endothelial cell line is represented by different symbols. Each point represents the average of four replicate wells. 
dotoxin for $24 \mathrm{~h}$ in both M-199/20\% FBS and M-199/0.5\% HSA. Thrombomodulin suppression did not occur in the absence of serum (data not shown).

The diminished thrombomodulin activity on endotoxintreated cells could be due to one of the following mechanisms. First, endothelial cells may express and/or secrete an APC inhibitor in response to endotoxin. We could exclude this possibility because no detectable APC inhibitor activity was observed when purified human APC $(1.55 \mu \mathrm{g} / \mathrm{ml})$ was added to cell-free media conditioned for $60 \mathrm{~min}$ on either control HUVEC or HUVEC incubated with $1 \mu \mathrm{g} / \mathrm{ml}$ endotoxin for the previous 24 h. We were also unable to detect cell-bound APC inhibitor activity when purified human APC $(1.55 \mu \mathrm{g} / \mathrm{ml})$ was incubated for $60 \mathrm{~min}$ on control or endotoxin-treated HUVEC, either in the presence or absence of human protein $\mathrm{S}(19.8 \mu \mathrm{g} / \mathrm{ml})$. Decreased thrombomodulin activity could also result from either a reduced affinity for thrombin or protein $\mathrm{C}$. One potential mechanism for these changes could be the induction of inhibitors of these interactions. To exclude these possibilities, we have characterized the kinetic properties of thrombomodulin on control and endotoxin-treated HUVEC (Figs. 7 and 8). Neither the dissociation constant $\left(K_{\mathrm{D}}\right)$ for thrombin nor the Michaelis constant $\left(K_{\mathrm{m}}\right)$ for protein $\mathrm{C}$ were substantially altered by endotoxin treatment. We have also observed that the rate of activation of the Gla-domainless form of protein $\mathrm{C}$ decreases in parallel to that of native protein $\mathrm{C}$ (data not shown), providing additional evidence that substrate recognition is unaltered by endotoxin treatment. Therefore we can exclude the production of a competitive inhibitor of the binding interaction of thrombin or protein $\mathrm{C}$ with thrombomodulin and can infer that the thrombomodulin that remains on the cell surface after endotoxin treatment is kinetically unaltered.

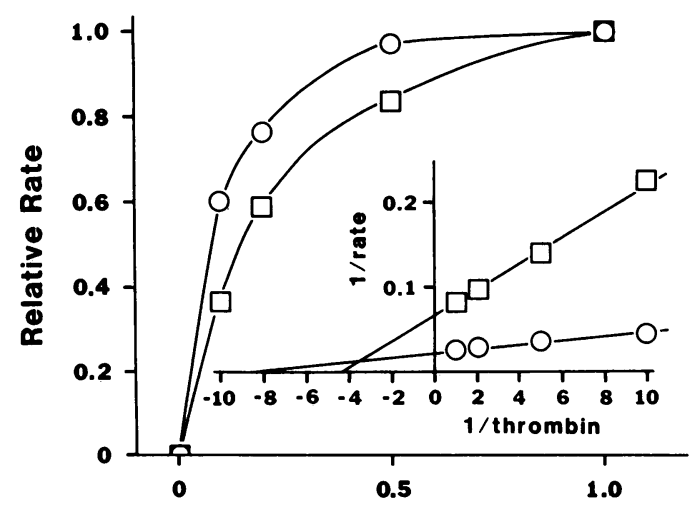

Thrombin (nM)

Figure 7. Effect of thrombin concentration on the rate of thrombincatalyzed protein $\mathrm{C}$ activation on control and endotoxin-stimulated HUVEC monolayers. Confluent HUVEC were incubated for $24 \mathrm{~h}$ in the presence or absence of endotoxin $(10 \mu \mathrm{g} / \mathrm{ml})$ in M-199/20\% FBS. At $24 \mathrm{~h}$, the monolayers were washed three times with serum-free $\mathrm{M}-199$. Protein $\mathrm{C}(1.0 \mu \mathrm{M})$ and thrombin at the indicated concentrations were added to each well and incubated for $1 \mathrm{~h}$ at $37^{\circ} \mathrm{C}$. After $1 \mathrm{~h}$ $10 \mu \mathrm{l}$ bovine antithrombin III $(1.67 \mathrm{mg} / \mathrm{ml})$ was added and $\Delta O D_{405} /$ min measured in the presence of $0.1 \mathrm{mM}$ Spectrozym CA. Reaction rates were normalized relative to the rate measured at $1 \mathrm{nM}$ thrombin. Points represent the average of assays performed on duplicate wells.

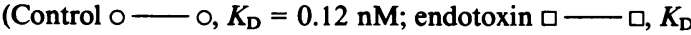
$=0.24 \mathrm{nM})$.

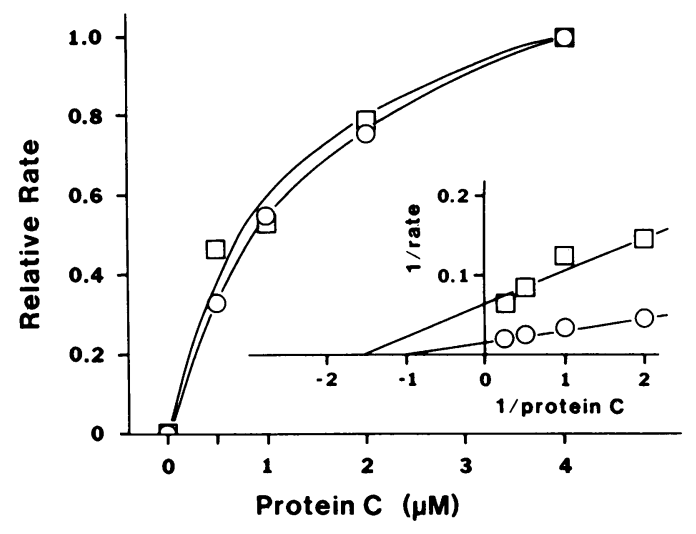

Figure 8. Effect of protein $\mathrm{C}$ concentration on the rate of thrombincatalyzed protein $C$ activation on control and endotoxin-stimulated HUVEC monolayers. Confluent HUVEC were incubated for $24 \mathrm{~h}$ in the presence or absence of endotoxin $(10 \mu \mathrm{g} / \mathrm{ml})$ in M-199/20\% FBS. At $24 \mathrm{~h}$, the monolayers were washed three times with serum-free $\mathrm{M}-199$. Thrombin ( $1 \mathrm{nM}$ ) and protein $\mathrm{C}$ at the indicated concentrations were added to each well and incubated for $1 \mathrm{~h}$ at $37^{\circ} \mathrm{C}$. After 1 $\mathrm{h}, 10 \mu \mathrm{l}$ bovine antithrombin III $(1.67 \mathrm{mg} / \mathrm{ml})$ was added and $\Delta \mathrm{OD}_{405} / \mathrm{min}$ measured in the presence of $0.1 \mathrm{mM}$ Spectrozym CA. Reaction rates were normalized relative to the rate measured at $4 \mu \mathrm{M}$ protein $\mathrm{C}$. Points represent the average of assays performed on duplicate wells. (Control $\bigcirc-\circ, K_{\mathrm{m}}=0.91 \mu \mathrm{M}$; endotoxin $\square-\square, K_{\mathrm{m}}$ $=0.63 \mu \mathrm{M})$.

\section{Discussion}

The host response to gram-negative septicemia, thought to be triggered by bacterial endotoxins, is complex and may culminate in an irreversible shock state and death. This shock state is frequently associated clinically with organ dysfunction, especially of the lung and kidney, and the development of disseminated intravascular coagulation. Pathologically, widespread vascular injury, focal thrombosis of small vessels and ischemic necrosis may be observed.

Endotoxin alone, however, does not cause detectable damage to human endothelial cells in vitro as assessed by light microscopy and ${ }^{51} \mathrm{Cr}$ release assays $(29,30)$. Our findings support these observations using a $\left[{ }^{3} \mathrm{H}\right]$ deoxyglucose release assay, which has been reported to be a more sensitive indicator of cellular injury than lactate dehydrogenase or ${ }^{51} \mathrm{Cr}$ release (27).

Neutrophils have been clearly implicated in the pathogenesis of endotoxin-induced lung injury (31), which can be abolished by prior depletion of circulating neutrophils (32). Neutrophils stimulated with a variety of agents, including lipopolysaccharide (29), zymosan-activated plasma (33), and phorbol myristate acetate (34), have all been shown to damage endothelial cells in vitro by generation of hydrogen peroxide and superoxide radicals. In addition, neutrophil-derived neutral proteases may also participate in endothelial cell injury $(35,36)$. Recently, however, it has become apparent that endotoxin may directly modulate endothelial cell hemostatic properties at extremely low concentrations in the absence of other cell types.

Colucci et al. (19) showed that cultured human endothelial cells release a fast-acting plasminogen activator inhibitor in response to endotoxin at concentrations comparable to those used in this study. That this effect is relevant in vivo was supported by their observation that rabbits injected with a single dose of endotoxin showed a 10 -fold rise in plasminogen activator (PA) 
inhibitor activity $3 \mathrm{~h}$ after injection. In addition, markedly increased levels of PA inhibitor were observed in patients with septicemia when compared with control patients.

Endotoxin has been shown by other investigators to promote de novo synthesis and expression of a procoagulant activity, identified as tissue factor on endothelial cells in vitro (15-18). Similarly, interleukin 1 has also been reported to stimulate tissue factor expression on human endothelial cells in vitro (37) and in vivo in rabbits (38). Tissue factor expression in response to both endotoxin (15), and interleukin 1 (37) was blocked by cycloheximide and/or actinomycin $\mathrm{D}$, indicating that de novo synthesis of tissue factor was involved.

Our data demonstrate a dose-dependent stimulation of surface expression of tissue factor on HUVEC in response to endotoxin. The time course of tissue factor expression is identical to that observed in previous studies (15-18) with maximal expression at $6 \mathrm{~h}$ and subsequent return to baseline by $24 \mathrm{~h}$. We report that endotoxin-stimulated tissue factor expression is accompanied by a sustained dose-dependent suppression of thrombomodulin activity that occurs at the same threshold endotoxin concentration that promotes tissue factor expression. Other investigators have recently observed that thrombomodulin expression declines after exposure to other inflammatory mediators, including interleukin 1 (38) and tumor necrosis factor (TNF) (39).

The mechanism of the suppression of thrombomodulin activity is unclear. We have ruled out three possible mechanisms for the decreased thrombomodulin activity on endotoxin-treated cells, namely the generation of an APC inhibitor, the inhibition to the thrombin-thrombomodulin interaction, and inhibition of the interaction between protein $\mathrm{C}$ and the thrombin-thrombodulin complex. We speculate that the depressed thrombomodulin activity we observe after endotoxin exposure is due to the in ternalization and/or degradation of surface bound thrombomodulin. Preliminary experiments measuring thrombomodulin activity and thrombomodulin antigen by radioimmunoassay in extracts of bovine aortic endothelial cells stimulated with TNF indicate that thrombomodulin is internalized and degraded after exposure to TNF (unpublished observations).

Several observations suggest that tissue factor expression, enhanced PA inhibitor secretion and suppression of thrombomodulin activity comprise a unified response of endothelial cells to inflammatory stimuli. First, the time courses of tissue factor expression in response to endotoxin, interleukin 1 (38) and TNF (39), are identical, as are the time courses of thrombomodulin suppression in response to these same agents. Second, tissue factor expression, thrombomodulin suppression, and PA inhibitor secretion (19) all occur in response to endotoxin in a dosedependent fashion and at essentially the same threshold endotoxin concentration. It is indeed possible that these changes in the properties of endothelial cells that result from exposure to endotoxin, interleukin 1, or TNF may occur as a result of the same primary intracellular events.

The physiological relevance of our in vitro observations is uncertain. The tissue factor levels that we and others (15) observe when endothelial cells are exposed to endotoxin is relatively low. Furthermore, the suppression of thrombomodulin activity is not complete, with most cell cultures decreasing to $\sim 50 \%$ of control levels. We believe that the extent of reduction in thrombomodulin concentration would result in a comparable reduction in the rate of protein $\mathrm{C}$ activation in response to in vivo thrombin formation. This might have an influence on the he- mostatic balance approximately equivalent to a $50 \%$ reduction in protein $\mathrm{C}$ levels since physiological protein $\mathrm{C}$ concentrations are below the $K_{\mathrm{m}}$ for the activation complex (40). An increased thrombotic tendency has been associated with familial decreases in protein $C$ to $50 \%$ of the normal level (41). In addition, binding thrombin to thrombomodulin decreases its procoagulant activity (42-44) and may increase the rate of reaction with antithrombin III (45). In addition to reducing the rate of protein $C$ activation, reduction in thrombomodulin concentration thus may increase both the thrombin procoagulant activity and clearance time in vivo. Even with these considerations, whether either of these effects alone or in combination are adequate to induce DIC or thrombosis in vivo is, of course, speculative. If one considers the much more favorable surface to volume ratio of a capillary bed relative to a tissue culture dish, however, we would speculate that these effects would comprise a thrombogenic effect in vivo. These effects may be significant in the pathogenesis of DIC in gram-negative sepsis.

\section{Acknowledgment}

This work was supported in part by the Cryptic Masons Atherosclerosis Foundation.

\section{References}

1. Moncada, S., R. Gryglewski, S. Bunting, and J. R. Vane. 1976. An enzyme isolated from arteries transforms prostaglandin endoperoxides to an unstable substance that inhibits platelet aggregation. Nature (Lond.). 263:663-665.

2. Levin, E. G., and D. J. Loskutoff. 1982. Cultured bovine endothelial cells produce both urokinase and tissue type plasminogen activator. $J$. Cell Biol. 94:631-636.

3. Stern, D., J. Brett, K. Harris, and P. Nawroth. 1986. Participation of endothelial cells in the protein C-protein $\mathrm{S}$ anticoagulant pathway: the synthesis and release of protein S. J. Cell Biol. 102:1971-1978.

4. Marcum, J. A., J. B. McKenney, and R. D. Rosenberg. 1984. Acceleration of thrombin-antithrombin complex formation in rat hindquarters via heparin-like molecules bound to the endothelium. J. Clin. Invest. 74:341-350.

5. Esmon, C. T., and W. G. Owen. 1981. Identification of an endothelial cell cofactor for thrombin-catalyzed activation of protein $\mathrm{C}$. Proc. Natl. Acad. Sci. USA. 78:2249-2252.

6. Walker, F. J., P. W. Sexton, and C. T. Esmon. 1979. Inhibition of blood coagulation by activated protein $\mathrm{C}$ through selective inactivation of activated factor V. Biochem. Biophys. Acta. 571:333-342.

7. Suzuki, K., J. Stenflo, B. Dahlback, and B. Teodorsson. 1983. Inactivation of human coagulation factor $\mathrm{V}$ by activated protein $\mathrm{C}$. $J$. Biol. Chem. 258:1914-1920.

8. Fulcher, C. A., J. E. Gardiner, J. H. Griffin, and T. S. Zimmerman. 1984. Proteolytic inactivation of human Factor VIII procoagulant protein by activated protein $\mathrm{C}$ and its analogy with Factor V. Blood. 63:486489.

9. Comp, P. C., and C. T. Esmon. 1981. Generation of fibrinolytic activity by infusion of activated protein $\mathrm{C}$ into dogs. J. Clin. Invest. 68 : 1221-1228.

10. Jaffe, E. A., L. W. Hoyer, and R. L. Nachman. 1974. Synthesis of anti-hemophilic factor antigen by cultured human endothelial cells. J. Clin. Invest. 52:2754-2764.

11. Meyer, D., and H. R. Baumgartner. 1983. Role of von Willebrand factor in platelet adhesion to the subendothelium. Br. J. Haematol. 54: $1-9$.

12. Loskutoff, D. J., J. A. van Mourik, L. A. Erickson, and D. Lawrence. 1983. Detection of an unusually stable fibrinolytic inhibitor produced by bovine endothelial cells. Proc. Natl. Acad. Sci. USA. 80:29562960.

13. Stern, D. M., M. Drillings, H. L. Nossel, A. Hurlet-Jansen, 
K. S. LaGamma, and J. Owen. 1983. Binding of factors IX and IXa to cultured vascular endothelial cells. Proc. Natl. Acad. Sci. USA. 80:41194123.

14. Stern, D. M., P. P. Nawroth, W. Kisiel, G. Vehar, and C. T. Esmon. 1985. The binding of factor IXa to cultured bovine aortic endothelial cells: Induction of a specific site in the presence of factors VIII and X. J. Biol. Chem. 260:6717-6722.

15. Colucci, M., R. Balconi, R. Lorenzet, A. Pietra, D. Locati, M. B. Donati, and N. Semararo. 1983. Cultured human endothelial cells generate tissue factor in response to endotoxin. J. Clin. Invest. 71:18931896.

16. Brox, J. H., B. Osterud, E. Bjorklid, and J. W. Fenton II. 1984. Production and availability of thromboplastin in endothelial cells: the effects of thrombin, endotoxin and platelets. Br. J. Haematol. 57:239246.

17. Lyberg, T., K. S. Galdal, S. A. Evensen, and H. Prydz. 1983. Cellular cooperation in endothelial cell thromboplastin synthesis. $\mathrm{Br}$. $J$. Haematol. 53:85-95.

18. Nawroth, P. P., D. M. Stern, W. Kisiel, and R. Bach. 1985. Cellular requirement for tissue factor generation by bovine aortic endothelial cells in culture. Thromb. Res. 40:677-691.

19. Colucci, M., J. A. Paramo, and D. Collen. 1985. Generation in plasma of a fast-acting inhibitor of plasminogen activator in response to endotoxin stimulation. J. Clin. Invest. 75:818-824.

20. Broze, G. J., and P. W. Majerus. 1980. Purification and properties of human coagulation factor VII. J. Biol. Chem. 255:1242-1247.

21. Comp, P. C., R. R. Nixon, M. R. Cooper, and C. T. Esmon. 1984. Familial protein $S$ deficiency is associated with recurrent thrombosis. J. Clin. Invest. 74:2082-2088.

22. D'Angelo, S. V., P. C. Comp, C. T. Esmon, and A. D'Angelo. 1986. Relationship between protein $C$ antigen and anticoagulant activity during oral anticoagulation and in selected disease states. J. Clin. Invest. 77:416-425.

23. Esmon, N. L., L. E. DeBault, and C. T. Esmon. 1983. Proteolytic formation and properties of $\gamma$-carboxyglutamic acid-domainless protein C. J. Biol. Chem. 258:5548-5553.

24. Laemmli, U. K. 1970. Cleavage of structural proteins during the assembly of the head of bacteriophage T4. Nature (Lond.). 227:680-685.

25. Miletich, J. P., C. M. Jackson, and P. W. Majerus. 1978. Properties of the factor Xa binding site on human platelets. J. Biol. Chem. 253: 6908-6916.

26. Edwards, R. L., and D. Perla. 1984. The effects of serum on monocyte tissue factor generation. Blood. 64:707-714.

27. Jaffe, E. A., R. L. Nachman, C. G. Becker, and C. R. Minick. 1973. Culture of human endothelial cells derived from umbilical veins. Identification by morphologic and immunologic criteria. J. Clin. Invest. 52:2745-2756.

28. Andreoli, S. P., R. L. Baehner, and J. M. Bergstein. 1985. In vitro detection of endothelial cell damage utilizing 2-deoxy-D- ${ }^{3} \mathrm{H}$-Glucose: Comparison with ${ }^{51}$ Chromium, ${ }^{3} \mathrm{H}$-Leucine, ${ }^{3} \mathrm{H}$-Adenine and LDH. $J$. Lab. Clin. Med. 106:253-261.

29. Yamada, O., C. F. Moldow, T. Sacks, P. R. Craddock, M. A. Boogaerts, and H. S. Jacob. 1981. Deleterious effects of endotoxin on cultured endothelial cells: An in vitro model of vascular injury. Inflammation. 5:115-126.

30. Harlan, J. M., L. A. Harker, G. E. Striker, and L. J. Weaver. 1983. Effects of lipopolysaccharide on human endothelial cells in culture. Thromb. Res. 29:15-26.

31. Brigham, K. L., W. C. Woolverton, L. H. Blake, and N. C. Staub. 1974. Increased sheep lung vascular permeability caused by Pseudomonas bacteremia. J. Clin. Invest. 54:792-804.

32. Heflin, A. C. Jr., and K. L. Brigham. 1981. Prevention by granulocyte depletion of increased permeability of sheep lung following endotoxemia. J. Clin. Invest. 68:1253-1260.

33. Sacks, T., C. F. Moldow, P. R. Chaddock, T. K. Bowers, and H. S. Jacob. 1978. Oxygen radicals mediate endothelial cell damage by complement-stimulated granulocytes. J. Clin. Invest. 61:1161-1167.

34. Weiss, S. J., J. Young, A. F. LoBuglio, A. Slivka, and N. F. Nimeh. 1981. Role of hydrogen peroxide in neutrophil-mediated destruction of cultured endothelial cells. J. Clin. Invest. 68:714-721.

35. Harlan, J. M., P. D. Killen, L. A. Harker, and G. E. Striker. 1981. Neutrophil-mediated endothelial injury in vitro. Mechanism of cell detachment. J. Clin. Invest. 68:1394-1403.

36. Smedly, L. A., M. G. Tonnesen, R. A. Saudhaus, C. Haslett, L. A. Guthrie, R. B. Johnston, Jr., P. M. Henson, and G. S. Worthen. 1986. Neutrophil-mediated injury to endothelial cells: Enhancement by endotoxin and essential role of neutrophil elastase. J. Clin. Invest. 77: 1233-1243.

37. Bevilacqua, M. P., J. S. Pober, G. R. Majeau, R. S. Cotran, and M. A. Gimbrone, Jr. 1984. Interleukin 1 (IL-1) induces biosynthesis and cell surface expression of procoagulant activity in human vascular endothelial cells. J. Exp. Med. 160:618-623.

38. Nawroth, P. P., D. A. Handley, C. T. Esmon, and D. M. Stern. 1986. Interleukin-1 induces endothelial cell procoagulant while suppressing cell surface anticoagulant activity. Proc. Natl. Acad. Sci. USA. 83:3460-3464.

39. Nawroth, P. P., and D. M. Stern. 1986. Modulation of endothelial cell hemostatic properties by tumor necrosis factor. J. Exp. Med. 163: 740-745.

40. Owen, W. G., and C. T. Esmon. 1981. Functional properties of an endothelial cell cofactor for thrombin-catalyzed activation of protein C. J. Biol. Chem. 256:5532-5535.

41. Griffin, J. H. 1984. Clinical studies of protein C. Semin. Thromb. Hemostasis. 10:162-166.

42. Esmon, C. T., N. L. Esmon, and K. W. Harris. 1982. Complex formation between thrombin and thrombomodulin inhibits both thrombin-catalyzed fibrin formation and factor $\mathrm{V}$ activation. J. Biol. Chem. 257:7944-7947.

43. Maruyama, I., H. H. Salem, H. Ishii, and P. W. Majerus. 1985. Human thrombomodulin is not an efficient inhibitor of procoagulant activity of thrombin. J. Clin. Invest. 75:987-991.

44. Jakubowski, H. V., M. D. Kline, and W. G. Owen. 1986. The effect of bovine thrombomodulin on the specificity of bovine thrombin. J. Biol. Chem. 261:3876-3882.

45. Owen, W. G. 1985. Regulation of expression and inhibition of thrombin. Thromb. Haemostasis. 54(1):57. (Abstr.) 